\title{
Infections in British clinical laboratories, 1982-3
}

\author{
NR GRIST, JAN EMSLIE \\ From the University of Glasgow and the Communicable Diseases (Scotland) Unit, Ruchill Hospital, Glasgow
}

SUMMARY During 1982-3, 31 specific and 12 uncharacterised infections were reported from 30 of 240 laboratories, representing 29223 person-years of experience. Thirteen cases of hepatitis included 10 of type $\mathrm{B}$ or non- $\mathrm{A}$, non-B hepatitis of probable occupational origin (attributable incidence 34.2 per 100000 person years) affecting haematology, biochemistry, and postmortem workers. Of nine cases of tuberculosis, three were probably acquired in the laboratory (attributable incidence 10.3 per 100000 person years) and affected microbiology, morbid anatomy, and postmortem staff. Microbiology staff also acquired, probably from the laboratory, four shigella infections and one each of brucella and herpes. The general community was the probable source of three cases of hepatitis A, two of rubella, and one of varicella. During the two years the risk of laboratory acquired infection mainly concerned the postmortem room and mortuary.

The survey of infections in British laboratories ${ }^{12}$ was continued for the two year period 1982-3 by the same method of questionnaires sent to members of the Association of Clinical Pathologists and to a supplementary list based on information previously provided by the Institute of Medical Laboratory Sciences.

\section{Fiaterial and methods}

The confidential questionnaire was essentially the same as that used for the previous survey ${ }^{2}$ but was modified to clarify the status of those non-graduate, non-medical laboratory scientific officer (MLSO) staff whom the previous survey suggested might be at increased risk of tuberculosis. The classification distinguishes between (a) qualified postmortem and mortuary technicians and $(b)$ postmortem and mortuary attendants and "morticians" (Table 1). Staff numbers recorded on 1 January 1983 and 1984 were used to calculate person years of exposure for the various groups, and from these figures incidences were calculated as in previous surveys. Supplementary information was obtained by follow up inquiry in cases of hepatitis and where information was incomplete or ambiguous.

\section{Results}

Returns were received from 240 laboratories, which ranged from a few single-department units with

Accepted for publication 28 February 1985 small numbers of staff (one as low as four) to large general and Blood Transfusion Service laboratories, some with over 200 staff, and one microbiological centre with almost 400 staff. Infections were reported from 30 of these.

Most of the laboratories (200) were in England, 24 in Scotland, 11 in Wales, and five in Northern Ireland. Two reports were excluded-one from Eire and one from Canada.

\section{INCIDENCE OF INFECTIONS}

The overall data are summarised in Table 1, which includes infections of all types, without distinction between those acquired in a laboratory and those acquired in the community. Hepatitis predominated (13 cases) followed by tuberculosis (9), shigellosis (4), and five other identified infections. Not shown in the table are five uncharacterised "bowel infections" reported in an outbreak affecting the staff (three MLSO, two medical) of a surgical cut up area and also the report from one biochemistry laboratory that seven staff had sick absences attributable to diarrhoea and vomiting during the period of the survey.

\section{Hepatitis}

Table 2 summarises the 13 cases. The three hepatitis A infections were apparently acquired in the community. The seven hepatitis B infections included one instance, accidentally discovered, of symptomless seroconversion in a medical biochemist. Occupational exposure was possible or probable in all seven of these infections, although circumstantial 
Table 1 Cases and incidence of infections in laboratory staff 1982-3

\begin{tabular}{|c|c|c|c|c|c|c|c|c|c|c|}
\hline \multirow[t]{2}{*}{ Grade and discipline } & \multirow{2}{*}{\multicolumn{2}{|c|}{$\begin{array}{l}\text { Population at risk } \\
\text { (person years) }\end{array}$}} & \multicolumn{8}{|c|}{ Reported infections (no of cases per 100000 person years) } \\
\hline & & & \multicolumn{2}{|l|}{ Hepatitis } & \multicolumn{2}{|c|}{ Tuberculosis } & \multicolumn{2}{|l|}{ Shigellosis } & \multicolumn{2}{|l|}{ Others } \\
\hline Medical (total) & 2816 & & $2(71)$ & & $4(142)$ & & 0 & & 0 & \\
\hline Morbid anatomy & & 1112 & & 0 & & $4(360)$ & & 0 & & 0 \\
\hline $\begin{array}{l}\text { Haematology } \\
\text { Biochemistry }\end{array}$ & & $\begin{array}{l}748 \cdot 5 \\
268\end{array}$ & & & & & & 0 & & 0 \\
\hline Microbiology & & $\begin{array}{l}208 \\
653\end{array}$ & & $\begin{array}{l}1(373) \\
0\end{array}$ & & $\begin{array}{l}0 \\
0\end{array}$ & & $\stackrel{0}{0}$ & & $\begin{array}{l}0 \\
0\end{array}$ \\
\hline Immunology & & $32 \cdot 5$ & & 0 & & 0 & & 0 & & 0 \\
\hline Unspecified & & 2 & & 0 & & 0 & & 0 & & 0 \\
\hline Science ${ }^{*}$ (total) & 1663 & & $1(60)$ & & 0 & & 0 & & 0 & \\
\hline Morbid anatomy & & $252 \cdot 2$ & & 0 & & 0 & & 0 & & 0 \\
\hline $\begin{array}{l}\text { Haematology } \\
\text { Biochemistry }\end{array}$ & & $\begin{array}{l}103 \\
811 \cdot 5\end{array}$ & & & & $\begin{array}{l}0 \\
0\end{array}$ & & $\begin{array}{l}0 \\
0\end{array}$ & & $\begin{array}{l}0 \\
0\end{array}$ \\
\hline Microbiology & & $405 \cdot 5$ & & $\begin{array}{l}1(123) \\
0\end{array}$ & & $\begin{array}{l}0 \\
0\end{array}$ & & $\begin{array}{l}0 \\
0\end{array}$ & & $\begin{array}{l}0 \\
0\end{array}$ \\
\hline Immunology & & $78 \cdot 5$ & & 0 & & 0 & & 0 & & 0 \\
\hline Other & & 12 & & 0 & & 0 & & 0 & & 0 \\
\hline MLSO* (total) & 17488 & & $7(40)$ & & $2(11)$ & & $4(23)$ & & $5(29)$ & \\
\hline Morbid anatomy & & 2745 & & & & 0 & & $\begin{array}{l}0 \\
0\end{array}$ & & 0 \\
\hline $\begin{array}{l}\text { Haematology } \\
\text { Biochemistry }\end{array}$ & & $\begin{array}{l}5148 \\
3930\end{array}$ & & $\begin{array}{l}4(78) \\
2(51)\end{array}$ & & & & $\begin{array}{l}0 \\
0\end{array}$ & & $1(19)$ \\
\hline Microbiology & & 5330 & & $1(19)$ & & $2(38)$ & & $4(75)$ & & $3(56)$ \\
\hline Immunology & & $269 \cdot 5$ & & 0 & & 0 & & 0 & & $1(371)$ \\
\hline Other & & $65 \cdot 5$ & & 0 & & 0 & & 0 & & \\
\hline Others (total) & 7256 & & $3(41)$ & & $3(41)$ & & 0 & & 0 & \\
\hline $\begin{array}{l}\text { Postmortem/mortuary } \\
\text { technicians }\end{array}$ & & 483 & & $2(414)$ & & $1(207)$ & & 0 & & 0 \\
\hline $\begin{array}{l}\text { Postmortem/mortuary } \\
\text { attendants }\end{array}$ & & 81 & & $1(1235)$ & & 0 & & 0 & & \\
\hline Nurses, phlebotomists, blood & & & & & & 0 & & 0 & & 0 \\
\hline $\begin{array}{l}\text { donor attendants } \\
\text { Laboratory assistants, }\end{array}$ & & $1005 \cdot 5$ & & 0 & & $1(99)$ & & 0 & & 0 \\
\hline $\begin{array}{l}\text { cytology screeners, } \\
\text { photographers }\end{array}$ & & 4 & & 0 & & & & & & 0 \\
\hline Domestics, washers & & $1304 \cdot 5$ & & 0 & & 0 & & 0 & & 0 \\
\hline Office administrators & & $3154 \cdot 5$ & & 0 & & & & 0 & & 0 \\
\hline $\begin{array}{l}\text { Others } \dagger \\
\text { Total (all groups) }\end{array}$ & & $796 \cdot 5$ & & 0 & & $1(126)$ & & 0 & & 0 \\
\hline Total (all groups) & 29223 & & $13(44 \cdot 5)$ & & $9(30 \cdot 8)$ & & $4(13 \cdot 7)$ & & $5(17 \cdot 1)$ & \\
\hline
\end{tabular}

${ }^{*}$ Science = graduate PTA staff; MLSO (medical Laboratory Scientific Officer) = PTB staff: PTA and PTB are the groupings used by the Whitley Counger for negotiations on pay and service.

tIncludes porters, storemen, works staff, and drivers.

evidence of this was noted in only two cases: one was a mortuary attendant who had cut himself three months previously and the other was a medical haematologist who had clinical contact outside the laboratory. Other (non-A, non-B) types of presumed viral hepatitis affected a MLSO (haematology) and a mortuary technician, who had no recognised exposure to hepatitis but had suffered cuts during his work and who was the only fatality in the survey. It is notable that these two cases and the hepatitis B cases were confined to staff in haematology (five), biochemistry (two), and mortuary (three) departments. The hepatitis B infection in a young, adult, male blood transfusion worker is the first reported from this specialty in these surveys. The incidences for occupational subgroups shown at the bottom of Table 2 are mostly calculated from single cases and are therefore difficult to interpret.

\section{Tuberculosis}

Table 3 lists the nine cases. Only three were likely to be infections acquired in the laboratory, and two of these concerned morbid anatomy or postmortem work. Incidences again are based on small numbers.

\section{Shigellosis}

Apart from hepatitis A, shigellas accounted for the only specifically diagnosed bowel infections (Table 4). As in $1979-81^{23}$ only microbiology MLSOs were affected. In one case the infection was acquired from a quality control culture.

\section{Other infections}

Table 5 shows the remaining specific infections. Only two (brucellosis and herpetic whitlow) were occupational in origin.

\section{Discussion}

This latest instalment of the continuing survey confirms that hepatitis infections still affect laboratory workers, though the incidence remains generally low. The incidences are calculated from small num- 
Table 2 Cases of hepatitis

\begin{tabular}{|c|c|c|c|c|c|}
\hline Type & Year & Occupation & Age & Sex & Comments \\
\hline $\begin{array}{l}\mathbf{A} \\
\mathbf{A} \\
\mathbf{A}\end{array}$ & $\begin{array}{l}1982 \\
1983 \\
1983\end{array}$ & $\begin{array}{l}\text { MLSO, microbiology } \\
\text { Science, biochemistry } \\
\text { MLSO, biochemistry }\end{array}$ & $\begin{array}{l}28 \\
37 \\
32\end{array}$ & $\begin{array}{l}\mathbf{M} \\
\mathbf{M} \\
\mathbf{M}\end{array}$ & $\begin{array}{l}\text { Hepatitis A epidemic in home area; VS* } \\
\text { Hepatitis A epidemic in home area; VS } \\
\text { Hepatitis A epidemic in schools, } \\
\text { home contact }\end{array}$ \\
\hline $\begin{array}{l}\mathbf{B} \dagger \\
\mathbf{B}+ \\
\mathbf{B}+\end{array}$ & $\begin{array}{l}1982 \\
1982 \\
1982\end{array}$ & $\begin{array}{l}\text { Medical, haematology } \\
\text { MLSO, haematology } \\
\text { MLSO, haematology } \\
\text { (blood transfusion) }\end{array}$ & $\begin{array}{l}45 \\
21 \\
24\end{array}$ & $\begin{array}{l}\mathbf{F} \\
\mathbf{M} \\
\mathbf{M}\end{array}$ & $\begin{array}{l}\text { Suspected from clinical contact; VA*, VS } \\
\text { VA, VS } \\
\text { No known exposure; VA, VS }\end{array}$ \\
\hline $\begin{array}{l}\mathbf{B}+ \\
\mathbf{B} \dagger \\
\mathbf{B} \dagger \\
\mathbf{B} \dagger \\
\mathbf{B}+\end{array}$ & $\begin{array}{l}1982 \\
1983 \\
1983 \\
1983 \\
1983\end{array}$ & $\begin{array}{l}\text { Mortuary technician } \\
\text { Medical, biochemistry } \\
\text { MLSO, biochemistry } \\
\text { MLSO, haematology } \\
\text { Mortuary attendant }\end{array}$ & $\begin{array}{l}59 \\
29 \\
26 \\
38 \\
58\end{array}$ & $\begin{array}{l}\mathbf{M} \\
\mathbf{M} \\
\mathbf{M} \\
\mathbf{M} \\
\mathbf{M}\end{array}$ & $\begin{array}{l}\text { VA: Dane particles; negative for both later } \\
\text { No illness; accidental finding; VA, VS } \\
\text { VA, VS } \\
\text { VA, VS } \\
\text { Cut at necropsy } 3 \text { months previously. } \\
\text { VA, negative later }\end{array}$ \\
\hline Non- A, Non-B† & 1982 & Mortuary technician & 53 & $\mathbf{M}$ & $\begin{array}{l}\text { Fatal; no known exposure; negative tests } \\
\text { for } \mathrm{HBs} \mathrm{Ag} \text {, anti-HBc, hepatitis A IgM, } \\
\text { Epstein-Barr virus, cytomegalovirus, } \\
\text { and Q fever; hepatitis A IgG present }\end{array}$ \\
\hline "Viral"† & 1983 & MLSO, haematology & 22 & $\mathbf{M}$ & $\begin{array}{l}\text { Negative tests for hepatitis } A \text { and } B \text {; } \\
\text { monospot test negative. Probably } \\
\text { non- } A \text {, non-B }\end{array}$ \\
\hline
\end{tabular}

* VS = homologous IgM antibody or seroconversion found.

VA $=$ homologous antigen detected.

†Cases possibly attributable to occupation.

MLSO = medical laboratory scientific officer .

Attributable incidence (per 100000 person years)

Medical, biochemistry $=373$ (one case hepatitis $B$ )

Medical, haematology $=134$ (one case hepatitis B; probably not from laboratory exposure)

MLSO, biochemistry $=25$ (one case hepatitis $B$ )

MLSO, haematology $=58$ (three cases hepatitis B) 19 (one case "viral hepatitis")

Postmortem/mortuary technician $=207$ (one case hepatitis B)

207 (one case non- $A$, non-B hepatitis)

Postmortem/mortuary attendant $=1235$ (one case hepatitis B)

Total staff (all groups) $=34.5$ (10/29 223).

Table 3 Cases of tuberculosis

\begin{tabular}{|c|c|c|c|c|}
\hline Year & Occupation & Age & Sex & Comments \\
\hline 1982 & Medical, morbid anatomy & 54 & $\mathbf{M}$ & Suspected recurrence \\
\hline 1982 & Medical, morbid anatomy & 32 & $\mathbf{M}$ & Reactivation of old lesion \\
\hline 1982 & Medical, morbid anatomy & 30 & $\mathbf{F}$ & Tuberculin conversion in contact of above \\
\hline $1982^{*}$ & MLSO, microbiology & 21 & $\mathbf{F}$ & Suspected laboratory infection \\
\hline 1982 & Phlebotomist & 45 & $\mathbf{F}$ & Reactivation of old lesion \\
\hline $1983^{*}$ & Medical, morbid anatomy & 44 & $\mathbf{M}$ & \\
\hline 1983 & MLSO, microbiology & 27 & $\mathbf{M}$ & $\begin{array}{l}\text { Strong family history of tuberculosis; } \\
\text { laboratory exposure improbable }\end{array}$ \\
\hline $\begin{array}{l}1983^{*} \\
1983\end{array}$ & $\begin{array}{l}\text { Postmortem technician } \\
\text { Storeman }\end{array}$ & $\begin{array}{l}57 \\
55\end{array}$ & $M$ & Suspected infection from cadaver \\
\hline 1983 & Storeman & 55 & $\mathbf{M}$ & Reactivation of old lesion \\
\hline
\end{tabular}

*Three cases possibly attributable to occupation.

Attributable incidence (per 100000 person years)

Medical, morbid anatomy $=90$ (one case)

MLSO, microbiology = 19 (one case)

Postmortem technician $=207$ (one case)

Total staff (all groups) $=10.3$ (3/29 223).

Table 4 Cases of shigellosis

\begin{tabular}{|c|c|c|c|c|}
\hline Year & Occupation & Age & Sex & Comments \\
\hline $\begin{array}{l}1982 \\
198 ? \\
1983 \\
1983\end{array}$ & $\begin{array}{l}\text { MLSO, microbiology } \\
\text { MLSO, microbiology } \\
\text { MLSO, microbiology } \\
\text { MLSO, microbiology }\end{array}$ & $\begin{array}{l}47 \\
47 \\
22 \\
29\end{array}$ & $\begin{array}{l}\mathbf{M} \\
\mathbf{M} \\
\mathbf{M} \\
\mathbf{M}\end{array}$ & $\begin{array}{l}\text { Shigella sonnei infection } \\
\text { S flexneri } 2 \text { infection; laboratory accident } \\
S \text { flexneri } 2 \text { infection } \\
S \text { boydii infection; finger contaminated } \\
\text { from quality control culture }\end{array}$ \\
\hline
\end{tabular}

All probably occupational: incidence 75 per 100000 person years (MLSO microbiology).

Incidence in total staff population $=14$ per 100000 person years (4/29 223). 
Table 5 Other infections $\dagger$

\begin{tabular}{|c|c|c|c|c|c|}
\hline Infection & Year & Occupation & Age & Sex & Comments \\
\hline Brucella melitensis* & 1982 & MLSO, microbiology & 25 & $\mathbf{M}$ & Blood cultures from unsuspected case \\
\hline Herpes (whitlow)* & 1983 & MLSO, microbiology & 20 & $\mathbf{F}$ & $\begin{array}{l}\text { Working on diagnosis of genital } \\
\text { herpes }\end{array}$ \\
\hline $\begin{array}{l}\text { Rubella } \\
\text { Rubella } \\
\text { Varicella }\end{array}$ & $\begin{array}{l}198 ? \\
1983 \\
1981 / 82\end{array}$ & $\begin{array}{l}\text { MLSO, immunology } \\
\text { MLSO, haematology } \\
\text { MLSO, microbiology }\end{array}$ & $\begin{array}{l}29 \\
27 \\
23\end{array}$ & $\begin{array}{l}\mathbf{M} \\
\mathbf{F}\end{array}$ & $\begin{array}{l}\text { Exposed to chickenpox at college and } \\
\text { from sister }\end{array}$ \\
\hline
\end{tabular}

*Occupational infections.

†In addition an outbreak of "bowel infection" affected two medical and three MLSO staff in a surgical cut up area; also seven biochemistry staff were sick with diarrhoea and vomiting in one laboratory during the two years.

bers and must be interpreted with caution. As in previous surveys, those affected by hepatitis of probable occupational origin were workers in haematology and biochemistry and, for the first time in these surveys, mortuary and postmortem workers. One mortuary technician without a recognised source of infection was the first worker to die of hepatitis in the series; he was affected by non- $A$, non-B hepatitis. Also for the first time in these surveys a case of hepatitis $B$ in a blood transfusion worker was recorded. The patient had no recognised exposure to the infection and was in the age and sex group for which non-occupational hepatitis B is most frequent.

In order to assist assessment of the results of the survey, incidences have been calculated for the cumulated data of the five years $1979-83$ for the two most prevalent and important infections: hepatitis B (plus non-A, non-B) and tuberculosis (Table 6). Although some of the denominators are still small, the calculated rates, which include both attributable and other cases, should be more reliable for comparison with future data and with corresponding rates for other populations. For tuberculosis the highest rates relate to mortuary and postmortem workers, both medical and other, and to microbiology MLSOs. Rates for hepatitis (types B and non-A, non-B combined) remain somewhat higher in haematology and biochemistry workers and, based on small numbers, in postmortem and mortuary technicians and attendants. Further observations in postmortem and mortuary workers are required to

Table 6 Incidence of hepatitis ( $B$ and non-A, non-B combined) and tuberculosis during the five years 1979-83

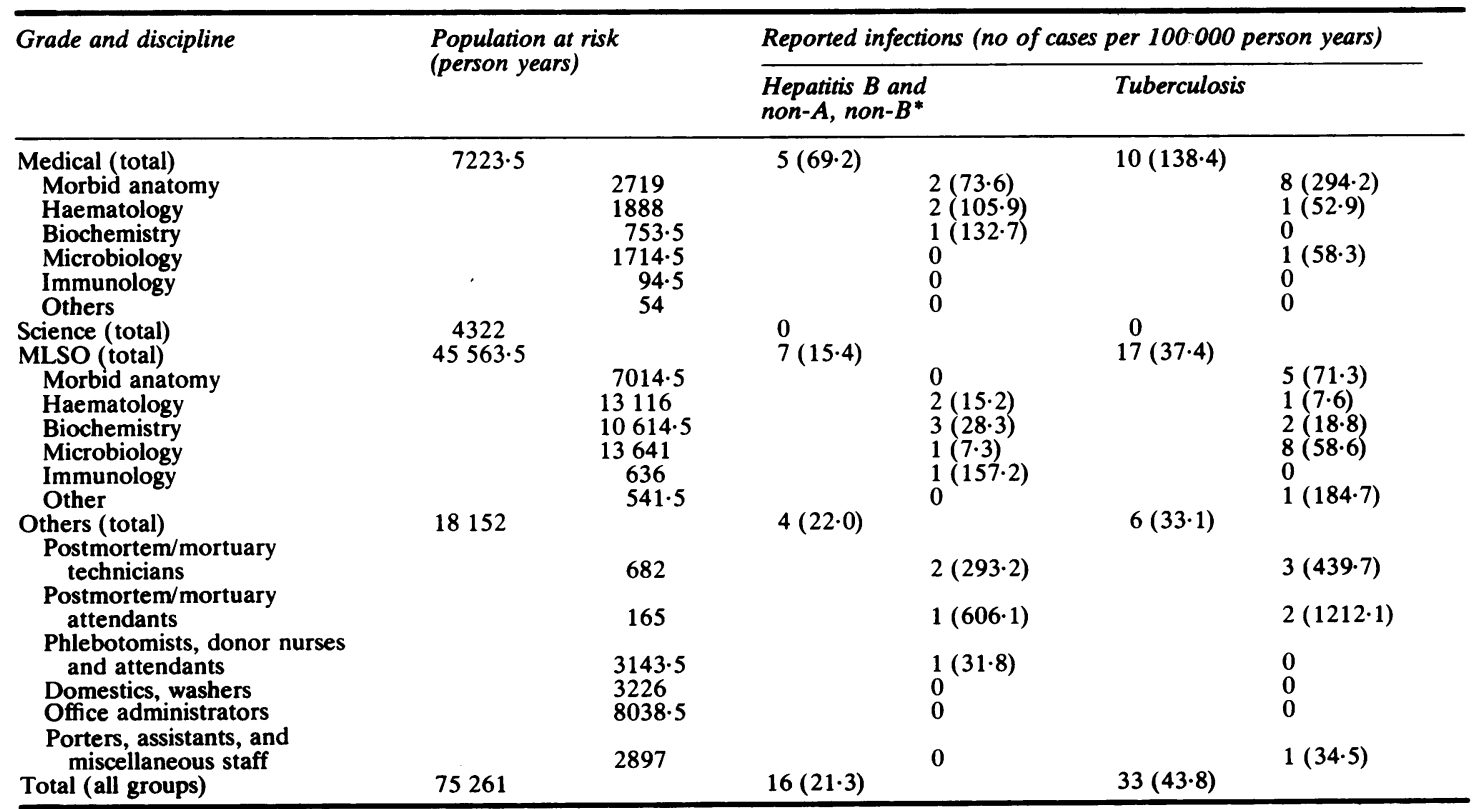

"Includes one case of incompletely investigated case of "viral hepatitis" negative in tests for hepatitis A and B. 
show whether this last finding is a chance fluctuation or the start of a trend, but in any case the postmortem room is confirmed as a risk area for acquiring infections.

Shigellas predominated as the commonest bowel pathogen acquired by microbiology workers, but only one infection was acquired from a proficiency testing sample. This contrasts with experience in the USA from 1977 to 1979 when 21 of 24 laboratory acquired typhoid infections resulting from proficiency tests or research on cultures deliberately introduced into the laboratories. ${ }^{4}$ Salmonella typhi has not been reported as causing laboratory infection during the present surveys (1979-83).

The brucella and herpes infections also affected microbiology staff, perhaps infected by aerosol and skin contact respectively. Once again, rubella and varicella, together with hepatitis $A$ and probably some diarrhoeal illnesses, gave a reminder that laboratory staff, like other persons, may acquire infections in the general community. These continuing surveys confirm the persistence of a real, but modest, risk of laboratory acquired infections mainly for workers with blood, with microorganisms, and in the postmortem room and mortuary. Their validity depends on the sustained voluntary cooperation of laboratory colleagues who responded to the biennial questionnaires and provided the overall denominator figures, which enable incidences to be calculated for comparison with previous and future years.

Although the staff numbers indicate a good level of response to the questionnaires, this is still less than $100 \%$. In order to refine the evaluation of the results it would be helpful if colleagues would advise us of any cases of hepatitis, tuberculosis, or other serious infections in laboratory staff during the sur- vey period 1982-3 which they believe are not recorded in our data. We would welcome brief details of the type of infection, age, sex, grade, and discipline, of the worker, the name of laboratory (but not the name of the person concerned), and information about the outcome of illness and the circumstances, if known, under which infection was acquired. This information will be handled with complete confidentiality as are the existing data on file. In response to a similar previous invitation, ${ }^{3}$ it was encouraging that no such "missed" cases were reported from laboratories participating in the 1975-79 survey.

We thank all those colleagues who have once more been patient and cooperated to provide information for the survey. We also thank the Association of Clinical Pathologists and the Institute of Medical Laboratory Sciences and our assistants at Ruchill Hospital for help with the survey.

\section{References}

' Grist NR. Hepatitis infections in clinical laboratory staff. Med Lab Sci 1981;38:103-9.

${ }^{2}$ Grist NR. Infections in British clinical laboratories 1980-81. J Clin Pathol 1983;36:121-6.

${ }^{3}$ Grist NR. Hepatitis and other infections in clinical laboratory staff, 1979. J Clin Pathol 1981;34:655-8.

${ }^{4}$ Blaser MJ, Hickman FW, Farmer III JJ, Brenner DJ, Balows A, Feldman RA. Salmonella typhi: The laboratory as a reservoir of infection. J Infect Dis 1980; 142:934-8.

Requests for reprints to: Professor NR Grist, Department of Infectious Diseases, Ruchill Hospital, Glasgow G20 9NB, Scotland. 